\title{
Numerical Simulation of Propagation of the Black Sea and the Azov Sea Tsunami Through the Kerch Strait
}

\author{
L. I. Lobkovsky ${ }^{1}$, R. Kh. Mazova ${ }^{2, *}$, E. A. Baranova ${ }^{2}, A$. M. Tugaryov ${ }^{2}$ \\ ${ }^{1}$ Shirshov Institute of Oceanology, Russian Academy of Sciences, Moscow, Russian Federation \\ ${ }^{2}$ Nizhny Novgorod State Technical University n. a. R. E. Alekseev, Nizhny Novgorod, Russian Federation \\ *e-mail: raissamazova@yandex.ru
}

\begin{abstract}
The present paper deals with the potential strong tsunamigenic earthquakes with the sources localized in the Black and Azov seas at the entrance and exit of the Kerch Strait, respectively. Since, at present time, the tsunami hazards are usually assessed for the critical earthquake magnitude values, potential strong earthquakes with a magnitude $\mathrm{M}=7$ are studied. The seismic sources of elliptical form are considered. When choosing the source location in the northeast of the Black Sea, the most seismically dangerous areas of the basin under consideration are allowed for. Numerical simulation is carried out within the framework of the nonlinear shallow water equations with the dissipative effects taken into account. Two possible scenarios of tsunami propagation at the chosen source locations are analyzed. The wave characteristics are obtained for a tsunami wave motion both from the Black Sea through the Kerch Strait to the Azov Sea. The symmetrical problem for a tsunami wave propagation from the Azov Sea through the Kerch Strait to the Black Sea is also considered. Spectral analysis of the tsunami wave field is carried out for the studied basin. The wave and energy characteristics of the tsunami waves in the area of the bridge across the Kerch Strait are subjected to the detailed examination and assessment.
\end{abstract}

Keywords: source of earthquake, tsunami waves, numerical simulation, spectral characteristics of a wave field.

Acknowledgements. The present research was carried under the financial support of the RSF (Project No. 14-50-00095).

For citation: Lobkovsky, L.I., Mazova, R.Kh., Baranova, E.A. and Tugaryov, A.M., 2018., Numerical Simulation of Propagation of the Black Sea and the Azov Sea Tsunami through the Kerch Strait. Physical Oceanography, [e-journal] 25(2), pp. 102-113. doi: 10.22449/1573-160X-2018-2$102-113$

DOI: $10.22449 / 1573-160 \mathrm{X}-2018-2-102-113$

(C) 2018, L. I. Lobkovsky, R. Kh. Mazova, E. A., Baranova, A. M. Tugaryov

(C) 2018, Physical Oceanography

Introduction. According to the data reported by hydrogeologists, the Kerch Strait is actually a spot of a tectonic fault, and both the Kerch and Taman shores are located on different tectonic blocks. Seismicity of the site is 9 points. The Kerch Strait bottom topography possesses a rather complex structure. The transverse profile of the strait floor is asymmetric. The strait itself is delimited into three parts by two natural lintels [1]. Water level oscillations in the Kerch Strait are of a different nature. The most significant in magnitude are the surge oscillations [2]. The Kerch Strait, separating the Kerch Peninsula of the Crimea and the Taman Peninsula of continental Russia, is the most important waterway connecting the Black and Azov Seas [3].

As is known, since the $7^{\text {th }}$ century BC, there was a communication between the western and eastern shores of the Kerch Strait. There were the repeated projects to build a bridge across the Kerch Strait, but the implementation of these projects was stopped by the WWI and WWII. And only in 1944 the Kerch railway bridge was built, which survived until February, 1945 [4]. In March, 2014, due to the reunification of the Crimea and Russia, preparations for the construction of the bridge became much more active. In June, 2014 the project was approved, and the 
construction of the bridge is planned to be completed by the end of 2018. The planned height of the bridge is $35 \mathrm{~m}$; its length is $19 \mathrm{~km}$.

As previously noted, the geological conditions in the Kerch Strait are quite complex due to seismicity, tectonic fault and weak soils. The bridge was designed taking into account the earthquake resistance for magnitudes $M$ up to 9.1, which occurs in the area approximately once every 1000 years [5-8]. However, in addition to taking into account the possibility of an earthquake in the Kerch Strait itself, it is necessary to consider the possibility of the appearance of tsunami waves coming from the basin of both the Black and Azov Seas.

There is scarce information about the tsunami of seismogenic nature in the Azov Sea [9-13]. Epicenters of historical relatively weak underwater earthquakes are concentrated in its southern and southwestern parts [5-7, 11]. The Azov Sea is a relatively small, being actually the Black Sea gulf. Meanwhile, here storms appear 61-98 times a year [14], and the passage of a tsunami has also been monitored. Therefore, the tsunami was recorded on September 11-12, 1927, December 28, 1939 and July 12, 1966, when waves from the Black Sea went through the Kerch Strait to the Azov Sea. The echoes of these tsunamis were registered in a number of points in the Azov Sea [15]. So, on October 28, 1969, the tsunami was manifested by a 5-meter water shaft in the Azov Sea southeast. In 1971, such an event, but on a larger scale, repeated for the same part of the Azov Sea [11, 14].

A number of authors have been engaged in the forecast of tsunamis in the Black and Azov Seas [7, 9, 10, 16 and 17]. So, in the work of Sergey F. Dotsenko and Andrey V. Ingerov, a numerical analysis of the tsunami wave propagation in the Azov Sea was carried out. According to this work, "the issue on the effectiveness of tsunami generation in the Azov Sea by seismic sources remains relevant and little explored" [10, p. 3]. This problem is currently very acute due to the bridge construction across the Kerch Strait.

Numerical simulation. For numerical simulation of the tsunami wave generation and propagation, the northeastern part of the Black Sea, the Kerch Strait and the southern part of the Azov Sea were considered (Fig. 1,a). There were virtual tide gauges registering the water level with a time step $t=1 \mathrm{~min}$ on the 4-meter isobath along these coasts (Fig. 1, $b$ ). Two scenarios of possible strong earthquakes with a magnitude $M=7$ from two hypothetical sources of an ellipsoidal form were considered. The dimensions of the earthquake sources, determined with by the Wells formulas [18], are about $16.4 \times 68 \mathrm{~km}$.
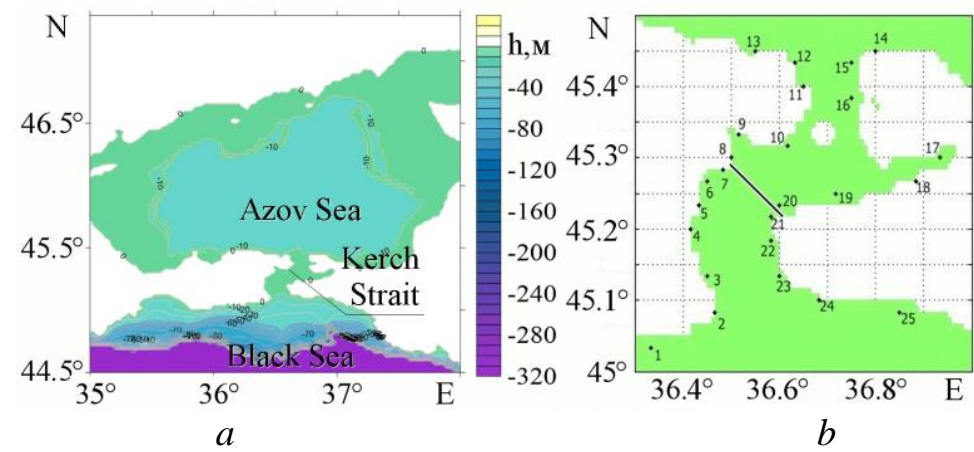

Fig. 1. Bathymetric map applied during the modeling, $-a$; a plan of virtual tide gauge location $-b$. The dark line is a schematic representation of the position of the bridge under construction 
A positive vertical displacement in the source up to $2.1 \mathrm{~m}$ was considered. A seismic source for the Scenario 1 implementation (the northeastern part of the Black Sea) is located in the zone of active faults of the Earth crust (Fig. 2, a); the source for Scenario 2 is in the southern part of the Azov Sea (Fig. 2, b). The computational domain in this problem was chosen in the $35-38^{\circ} \mathrm{E}, 44.5-47.5^{\circ} \mathrm{N}$ with a grid including the number of nodes $345 \times 361=124545$. The Black Sea bathymetry with the $500 \mathrm{~m}$ resolution was used for the simulation.

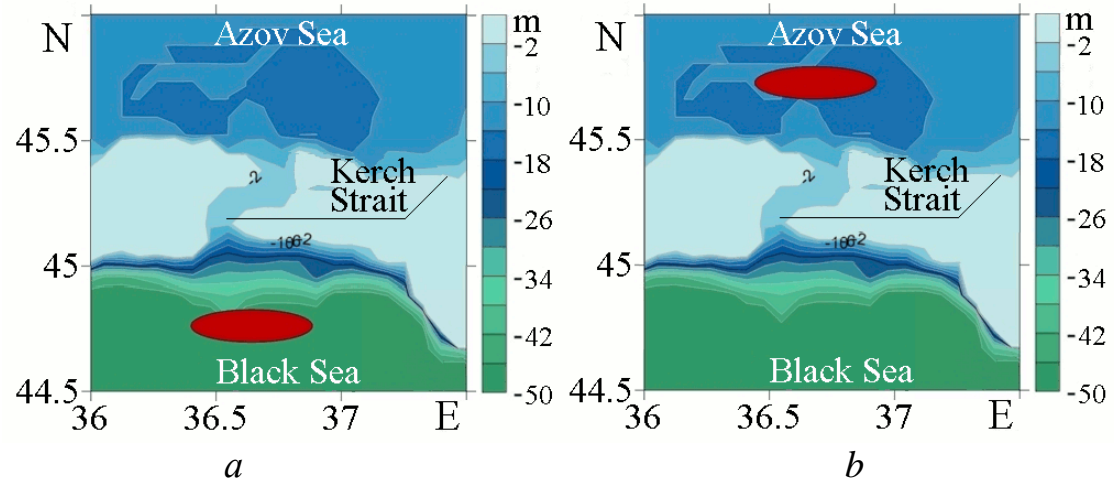

Fig. 2. The position of the considered earthquake source by Scenario $1(a)$ and Scenario $2(b)$

The simulation was carried out with a time step of $1 \mathrm{~s}$. In the last seaward point at a depth of $4 \mathrm{~m}$ the condition of total reflection (vertical wall) is set, allowing to fix the maximum and minimum values of the water level displacement at this depth. In the numerical solution, the scheme analogical to the scheme [19] was applied.

To describe the wave generation and propagation process caused by processes in the seismic source, a nonlinear system of shallow water equations was used in a two-dimensional formulation with allowance for dissipative effects and bottom friction [20-22].

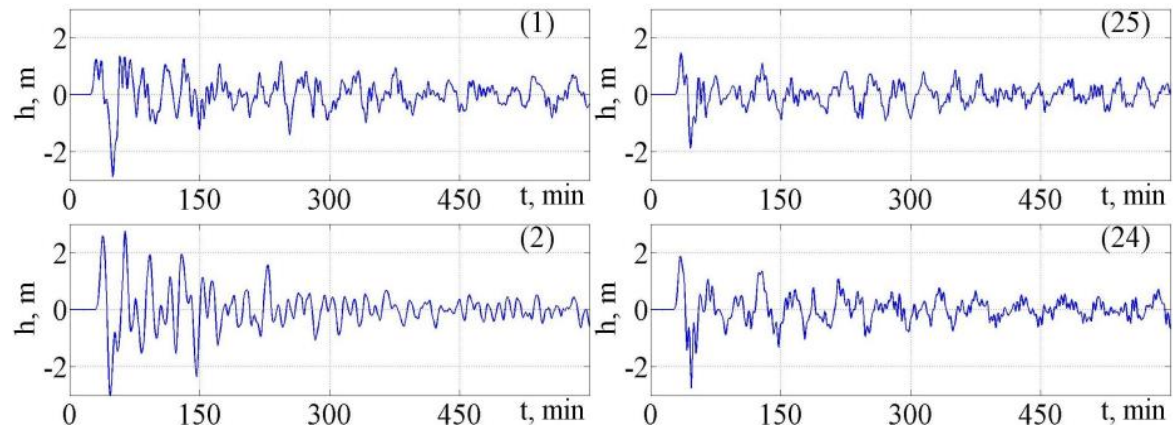

Fig. 3. The data from 4 virtual tide gauges located at the Kerch Strait entrance from the Black Sea for Scenario 1. Virtual tide gauge number is indicated in the upper right corner: (1) - Yakovenkovo; (2) - Zavetnoye; (24) - Volna; (25) - Artyushchenko

When the numerical simulation implementing, wave displacement and velocity fields along the northeastern Black Sea coast, the coasts of the Azov Sea and the 
Kerch Strait were obtained. In Fig. 3, when implementing Scenario 1, the data from virtual tide gauges can be seen. Their layout is shown in Fig. 1, $b$. The calculated tide gauges are shown for 1,2, 24 and 25 points located at the strait entrance. It can be clearly seen that the maximum spread in sea level oscillations at these points is almost $5 \mathrm{~m}$ : from +2.3 to $-2.5 \mathrm{~m}$. For the same scenario in Fig. 4 the positions of the wave fronts are shown.

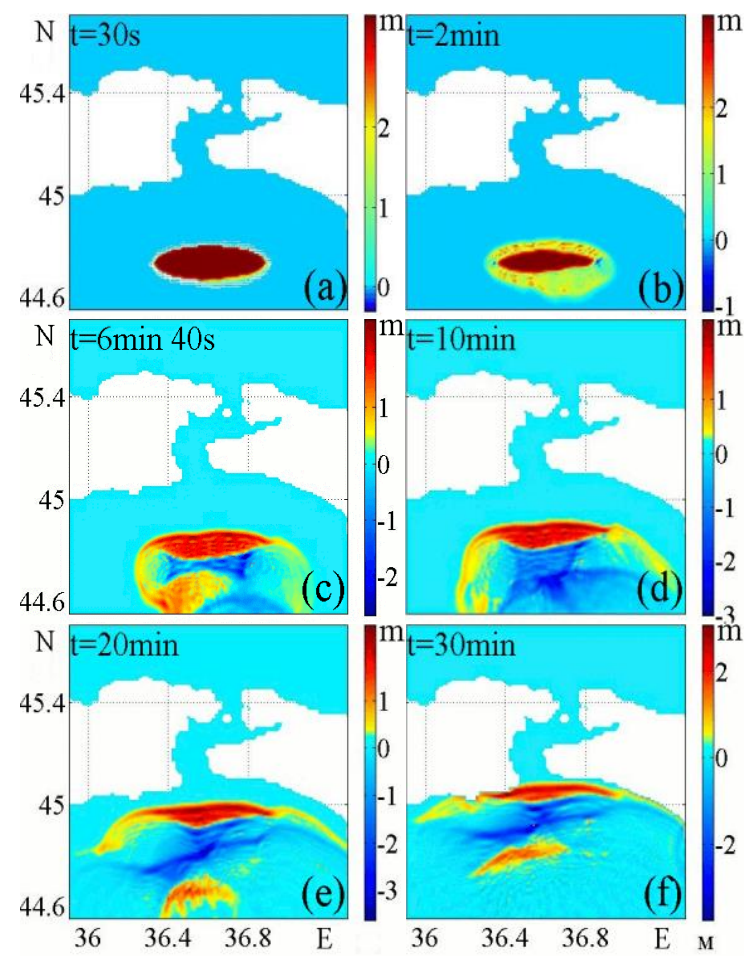

Fig. 4. Position of tsunami wave fronts for 6 time moments when implementing Scenario 1

It is well seen (Fig. 4,e), that wave front up to $2.3 \mathrm{~m}$ in height approaches the Kerch Strait entrance 30 minutes after the earthquake.

Fig. 5 shows the calculated tide gauges for the points located on the western and eastern coasts of the Kerch Strait (Fig. 1,b). It can be seen that the maximum heights of the first waves fitting almost all the points (except the $22^{\text {nd }}$ one) do not reach $1 \mathrm{~m}$.

Fig. 6 shows a picture of the passage of a tsunami wave along the Kerch Strait for this scenario. The leading edge of the elevation wave has a convex, arcuate shape along the entire width of the strait. The height of the crest in the strait an hour after the beginning of the event reaches $1.5 \mathrm{~m}$. After 1 hour and 13 minutes, the right edge of the wave front up to $0.7 \mathrm{~m}$ in height (point 20 in Fig. 5) reaches the bridge pillars in the Tuzla Spit area. The rest of the front continues to spread northward and after about 8 minutes it strikes southern coast of the Kamysh-Burun Bay and reaches the western bridge pillars. The height of the crest of the wave in point 7 (Fig. 5) is about $0.7 \mathrm{~m}$. After the passage of the Tuzla Spit, the height of the right half of the wave front is almost halved and the wave front is turned toward the 
Taman Bay (Fig. 6, c). The middle part of the wave front extends toward the northern coast of the Kerch Bay and reaches it in 10 minutes with a height of about $1 \mathrm{~m}$ (Fig. 6, d). In the rest of the bay, the wave height at the 4-meter isobath is about $0.5 \mathrm{~m}$. The water level decrease by about $1 \mathrm{~m}$ is observed at this time near the bridge.

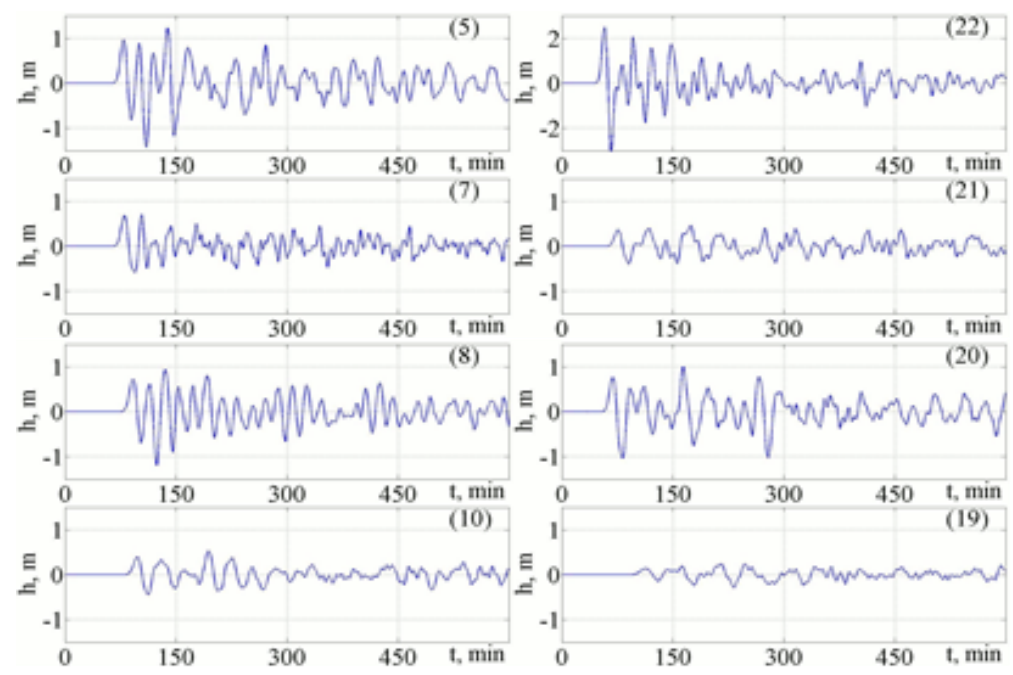

Fig. 5. The data from 8 virtual tide gauges located along the Kerch Strait for Scenario 1: (5) - the southern part of the city of Kerch; (7) - the southwestern edge of the bridge; (8) - the northwestern edge of the bridge; (10) - the eastern part of the city of Kerch; (19) - Taman; (20) - the northeastern edge of the bridge; (21) - the southeastern edge of the bridge; (22) - Tuzla Island shore

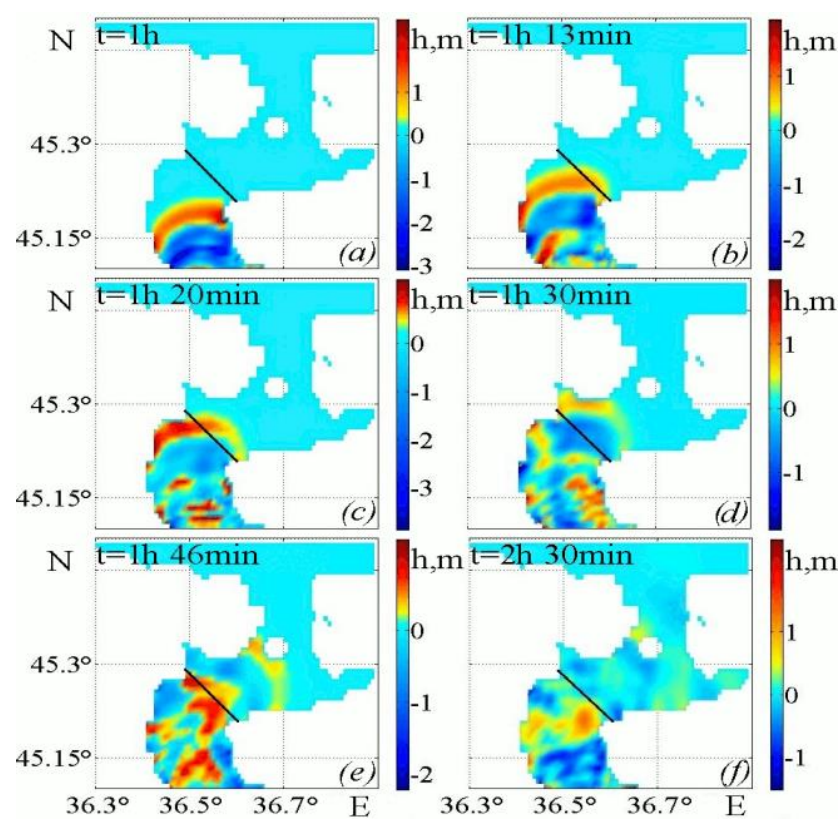

Fig. 6. Positions of tsunami wave fronts and water level distribution in the Kerch Strait basin for 6 time moments when implementing Scenario 1 
At $t \sim 1 \mathrm{~h} 46 \mathrm{~min}$ from the seismic process start (Fig. 6, d) a wave crest consisting of two parts approaches the bridge. The bridge center is subjected to the attack of a pointed shape wave crest, precisely in the area of the Tuzla Spit, where the eastern bridge pillars are located. Another section of the wave front attacks the bridge pillars at the site of its bending near the Ak-Burun Cape. The height of the second crest of the wave in point 7 (Fig. 5) is also about $0.7 \mathrm{~m}$. At the same time, the leading front of the wave reaches the Chushka Spit, but the crest height is less than $0.5 \mathrm{~m}$. Approximately 2 hours $30 \mathrm{~min}$ after the seismic process start, the area of the Tuzla Spit (Fig. 6e) is subjected to an attack of the wave with a crest of about $1 \mathrm{~m}$ height (point 20 in Fig. 5) again.

According to the data of Fig. 5 and 6, it can be concluded that when the wave moves along the entire length of the Kerch Strait, the maximum value of the height of its leading edge is about $2.2 \mathrm{~m}$ (point 22). The wave passes through the whole strait and reaches the water area of the Azov Sea in 2 hours 20 minutes (Fig. 7), while having a maximum height of only about $0.2 \mathrm{~m}$.
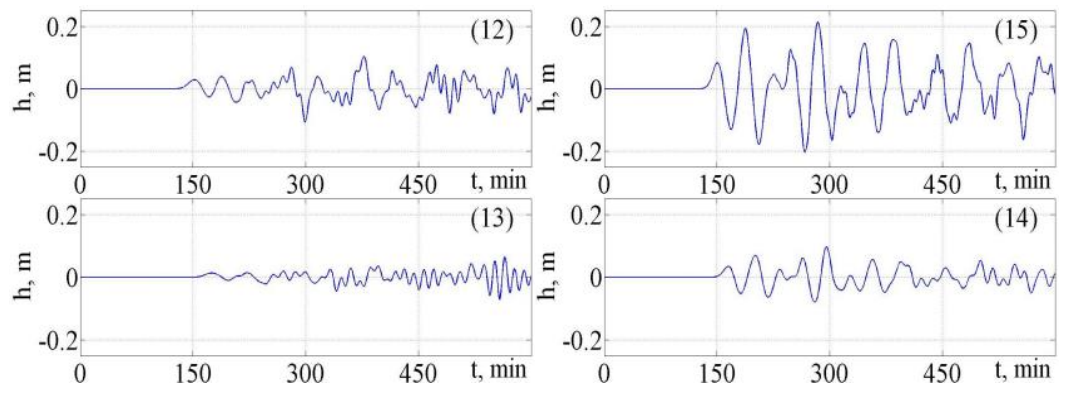

Fig. 7. The data from 4 virtual tide gauges for Scenario 1 located at the exit from the Kerch Strait to the Sea of Azov: (12) - Ovosiny; (13) - Yurkino; (14) - Priazovskiy; (15) - Ilyich
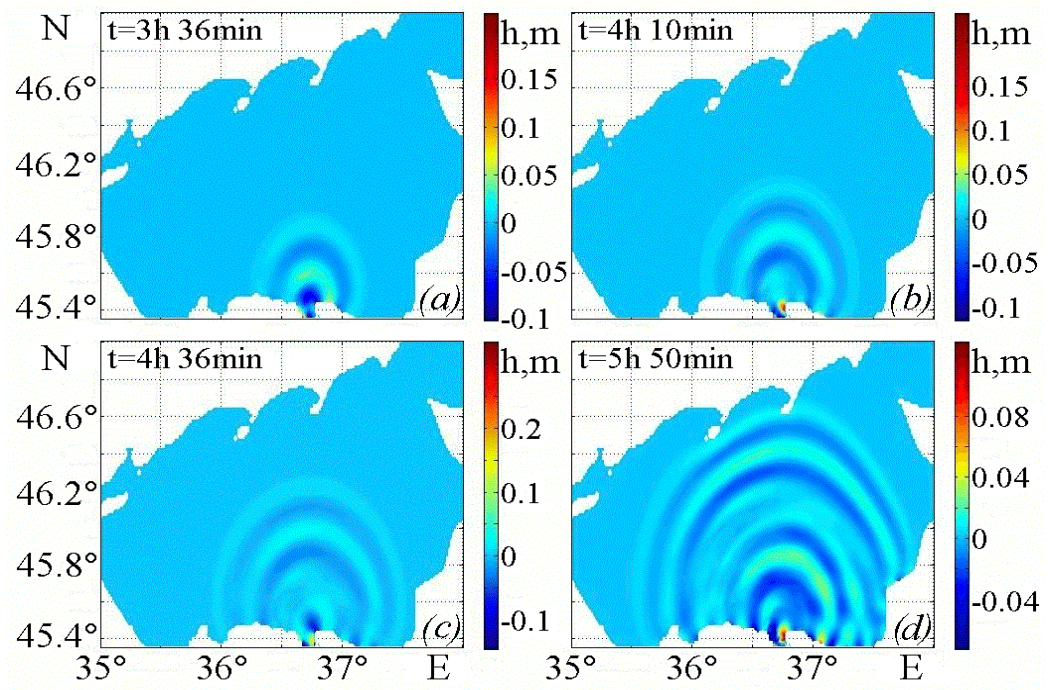

Fig. 8. Positions of tsunami wave fronts and water level distribution in the basin of the Sea of Azov for 4 time moments by Scenario 1 
The tsunami fronts in the Azov Sea basin are of a circular shape (Fig. 8). The mean wave height is $0.2 \mathrm{~m}$. A wave with a $0.05 \mathrm{~m}$ mark reaches the northern coast of the sea in 5 hours 50 minutes (Fig. 8,d). During wave propagation in the Azov Sea, the maximum wave height remains the same as at the Kerch Strait exit, which is clearly seen from data from the tide gauges 12-15 (Fig. 7).

During Scenario 2 implementation, when the earthquake source is localized in the Azov Sea opposite the entrance to the Kerch Strait, the picture of tsunami wave passage across the strait significantly changes (Fig. 9, 10). Unlike Scenario 1, the leading front of the elevation wave has a flat shape after entering the strait and passing the Chushka Spit. The crest height in the strait is of the order of $0.5 \mathrm{~m} 1 \mathrm{~h}$ after the beginning of the event. After $1 \mathrm{~h} 46 \mathrm{~min}$, the wave front (points 19, 20 in Fig. 10) reaches the southern coast of the Taman Bay with a crest height of $0.5 \mathrm{~m}$ in the Taman area. It also reaches the bridge pillars in the area of the Tuzla Spit with a wave height of up to $0.4 \mathrm{~m}$. The rest of the front continues to spread in the southwestern direction, reaching the northern coast of the Kerch Bay. After 8 min it collapses on the southern coast of the Kamysh-Burun Bay and reaches the eastern pillar of the bridge. The height of the wave crest in point 7 (Fig. 10) is about $0.7 \mathrm{~m}$.

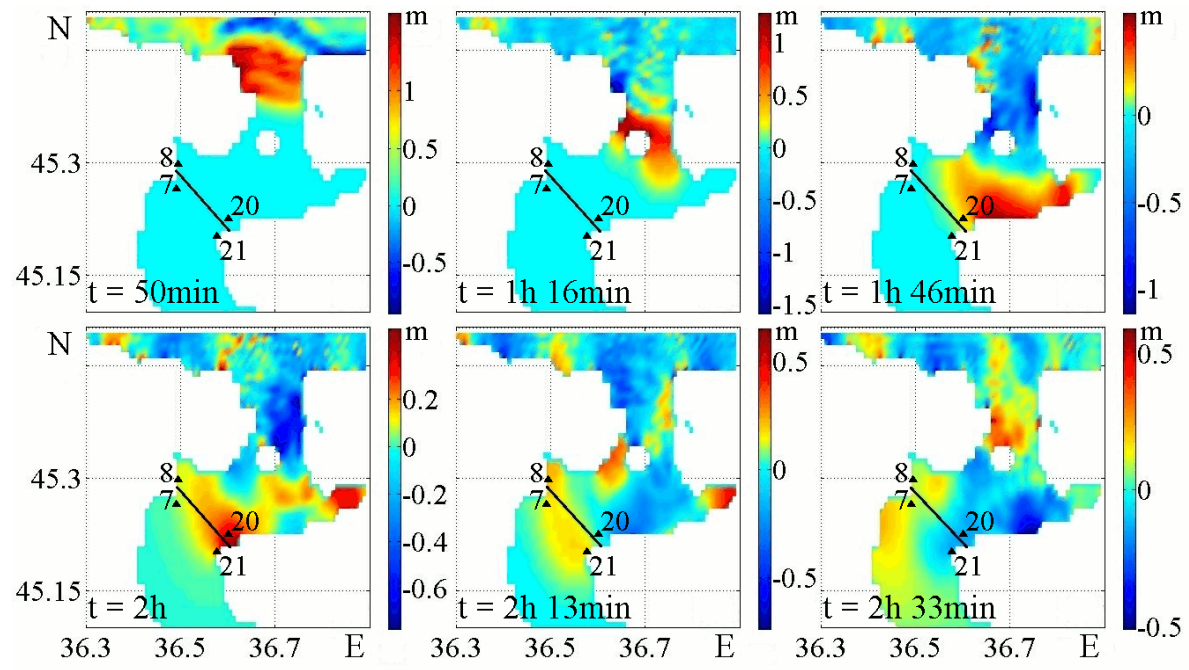

Fig. 9. Positions of tsunami wave fronts and water level distribution in the Kerch Strait basin for 6 time moments when implementing Scenario 2

The middle part of the wave front extends towards the southern coast of the Kerch Bay and reaches it in 10 minutes with a height of up to $0.5 \mathrm{~m}$ near the port of Taman (Fig. 9, d). The right part of the wave front extends in the southwestern direction, reaching the western bridge pillars and the southern coast of the Kerch Bay. Two hours after the tsunami generation, the wave front reaches the bridge pillars along its entire length and enters the Kerch Bay (Fig. 9, d). The wave height of $0.4 \mathrm{~m}$ in the Tuzla Spit area (points 20, 21 in Fig. 10) drops to $0.2 \mathrm{~m}$ in the AkBurun Cape area. (points 7, 8 in Fig. 10). After about 13 minutes, the wave passes through the bridge area, remaining only in the Kerch Bay water area. With the further propagation, the wave front becomes more slightly sloping with 
a maximum height of about $0.2 \mathrm{~m}$, reaching the coast of the Kamysh-Burun Bay and then dissipating through the strait.
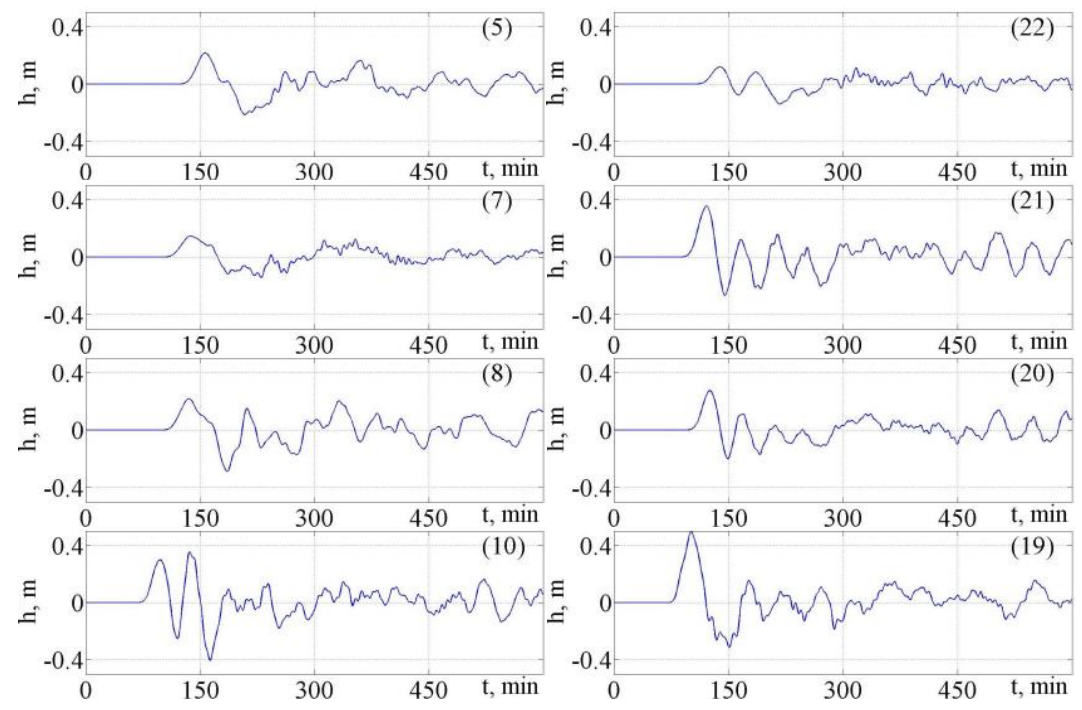

Fig. 10. The data from 8 virtual tide gauges located along the Kerch Strait for Scenario 2: (5) - the southern part of the city of Kerch; (7) - the southwestern edge of the bridge; (8) - the northwestern edge of the bridge; (10) - the eastern part of the city of Kerch; (19) - Taman; (20) - the northeastern edge of the bridge; (21) - southeastern edge of the bridge; (22) - Tuzla Island shore

Spectral analysis. To analyze the passage of waves through the Kerch Strait, a spectral analysis of the wave process was carried out using the data obtained from virtual tide gauges 2, 7, 8, 12, 15, 20, 21 and 25 (Fig. 1, b) [19, 20]. Fig. 11, a shows a wavelet spectrogram for point 2 , located on the western boundary of the Kerch Strait entrance.

It is clearly seen that in the interval $\Delta t 0-300 \mathrm{~min}$, the wave energy is distributed almost uniformly throughout the frequency domain with an intensity of up to $50 \mathrm{~dB}$, however, the bulk of the wave energy is concentrated in the low-frequency domain within the range $1-2.5 \mathrm{cph}$, which corresponds to $\mathrm{T} \sim 15-60$-minute waves over a time interval $\Delta t 0-180 \mathrm{~min}$. The intensity is about $60 \mathrm{~dB}$. At the southern entrance to the strait, in point 25 , the energy is distributed more evenly over the entire observation range, which is clearly seen on the wavelet spectrogram for this point (Fig. 11,b). The largest wave intensity, up to $55 \mathrm{~dB}$, within the range of 1-3 cph is observed in the interval $\Delta \mathrm{t} 20-80 \mathrm{~min}$ and up to $2 \mathrm{cph}$ in the interval $\Delta \mathrm{t}$ 200-380 min. When approaching the Crimean Bridge a part of the wave energy is lost (Fig. 11, c, 11, d), the low-frequency component of 1-2 cph prevails. The intensity is about $50 \mathrm{~dB}$. In the area of the western part of the bridge, moving from point 7 to point 8 , the energy concentration in the frequency range reaches $4 \mathrm{cph}$.

For the eastern part of the strait in point 20 in front of the bridge, three time intervals $\Delta t: \sim 50-100, \sim 150-200, \sim 250-300 \mathrm{~min}$ are well seen on the spectrogram (Fig. 11e) in the frequency range $1-3 \mathrm{cph}$. The intensity is $50 \mathrm{~dB}$. At the exit from the Kerch Strait, all the wave energy is concentrated in a narrow low-frequency interval of 1-2 cph with a significantly weakened wave energy (Fig. 11, $e, 11, g$ ). 
In the time interval $\Delta t 100-600 \mathrm{~min}$ in the wavelet spectrograms for the tide gauges 12 and 15 there is practically a permanent component with a frequency $f \sim 1-2 \mathrm{cph}$ (30-60 min period) and the intensity up to $40 \mathrm{~dB}$. Thus, it can be seen that when the waves pass through the Kerch Strait, the wave energy of the high-frequency interval is practically lost, and the low-frequency interval is significantly weakened.
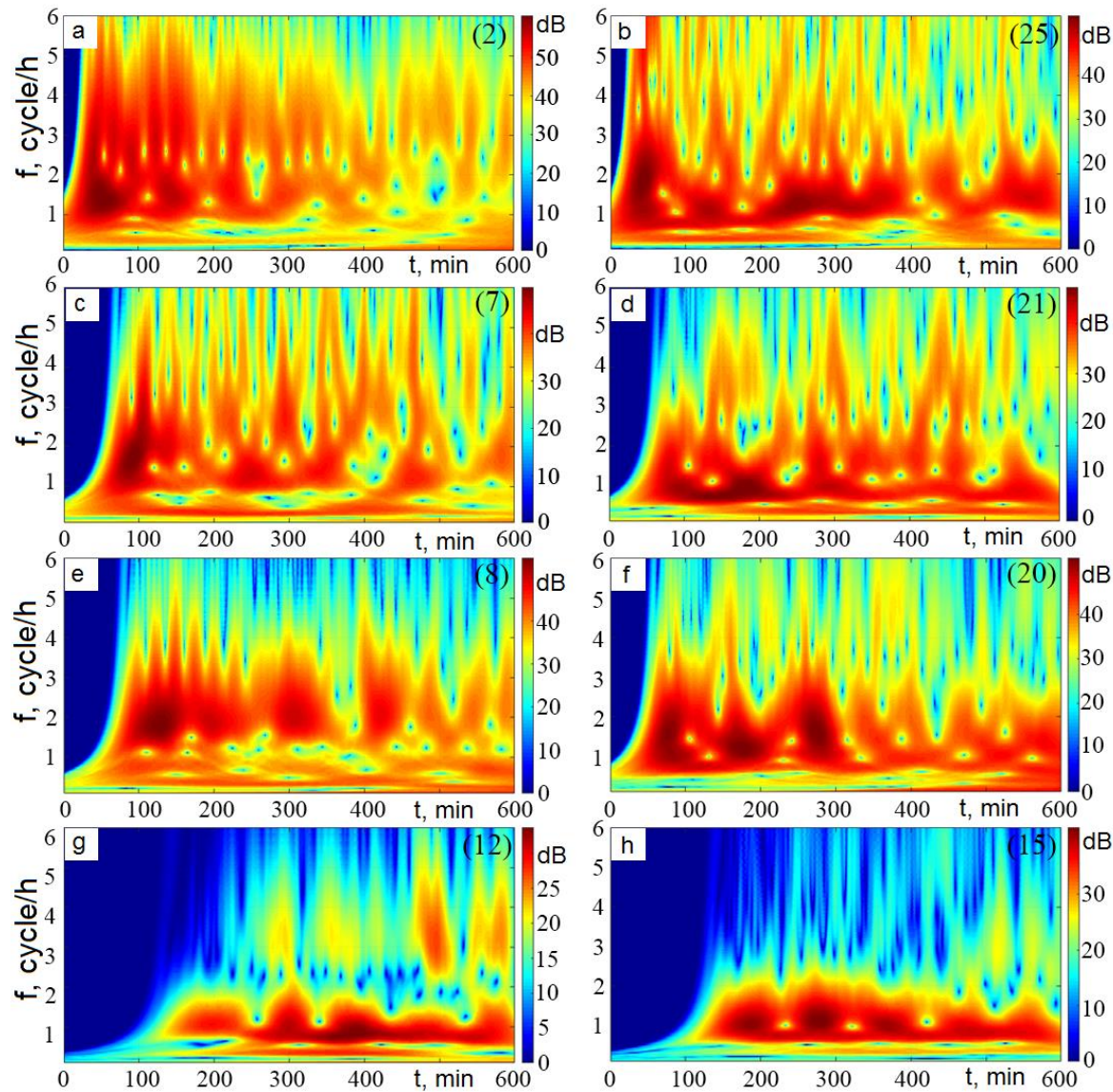

Fig. 11. Energy characteristics of tsunami waves in the Kerch Strait

Conclusion. The calculation carried out shows that with possible strong earthquakes in the Black Sea of magnitude $M=7$, the heights of tsunami waves in the Kerch Strait near the bridge under construction can reach 1.5-2 m. When a tsunami wave moves from the Black to Azov Sea through the Kerch Strait the water flow velocity near the western pillars of the bridge that surrounds the AkBurun Cape, can exceed $8.5 \mathrm{~m} / \mathrm{s}(\sim 30 \mathrm{~km} / \mathrm{h})$, which should be taken into account in the bridge operation. In the eastern part of the bridge, the Tuzla Spit serves as a natural dam, extinguishing the destructive energy of the tsunami. One hour and 45 minutes after the tsunami generation, a wave crest up to $1 \mathrm{~m}$ high approaches the middle of the bridge, while the left side of the wave front attacks the western part of the bridge. A wave with a height of up to $1 \mathrm{~m}$ reaches the eastern part of the bridge in 
the Tuzla Spit area after 45 minutes. Further propagation of the wave occurs with lower heights.

In the reverse problem statement, when the potential source of the tsunami is located in the Azov Sea, the wave heights in the Kerch Strait are much smaller, up to $0.5 \mathrm{~m}$. The wave will mainly affect the southern coast of the Taman Bay, so that when a part of the wave front approaches the bridge line, its energy will have already been substantially canceled. A characteristic feature of the tsunami propagating through the strait is the flat shape of the wave front as when moving along the Chushka spit, or when approaching directly to the bridge. Unlike the previous case, when the tsunami source is located in the Black Sea, an elevation wave attacks the bridge across its entire width - from the Tuzla Spit in the east to the AkBurun Cape in the west. Note that the wave height here is significantly less than in the first case, but the entire bridge construction is immediately attacked. The results obtained are in good agreement with both the few observational data and the research of other authors.

According to the analysis carried out, during the passage of a tsunami wave from the Black Sea through the Kerch Strait on the section to the Crimean Bridge, its amplitude and power are significantly damped. The wave front reaches and passes through the eastern bridge pillars in the Tuzla Spit area within an hour after the tsunami generation. In this part of the bridge, the width of the frequency domain, where the main energy is concentrated, increases by 1.5 times $(1-3 \mathrm{cph})$, and the intensity also increases by 1.3 times, although the main frequency component of the tsunami wave remains practically unchanged $(\sim 1-2 \mathrm{cph})$.

On the instantaneous power graph, when passing these supports, 3 peaks appear instead of the one observed at the approach. Through the western bridge pillars near the Ak-Burun Cape, the wave front passes about $10 \mathrm{~min}$ after reaching the eastern pillars. Although the frequency range width of the domain the main energy is concentrated in during the passage of the area of these pillars, increases insignificantly $(1-3.5 \mathrm{cph})$, the time interval expands more than 2 times at practically constant intensity $(\sim 50 \mathrm{~dB})$. The main frequency component of the tsunami wave during the passage of the area of the western bridge pillars also increases by 1.5 times approximately.

\section{REFERENCES}

1. Polubok, T.M., 2013. Izuchennost' Processov Litologo-Geomorfologicheskikh Izmeneniy Dna Kerchenskogogo Proliva [The tendencies of Modern Litologic Geomorphological Changes of Bottom of the Kerch Channel]. Bulletin of Odessa State Environmental University, iss. 15, pp. 187-196 (in Ukrainian).

2. Eremeev, V.N., Ivanov, V.A. and Ilyin, Yu.P., 2003. Okeanograficheskie Usloviya i Ekologicheskie Problemy Kerchenskogo Proliva [Oceanographic Conditions and Ecological Problems in the Kerch Strait]. Marine Ecological Journal, 2 (3), pp. $27-40$ (in Russian).

3. Tormasov, Yu.B., 2014. Proekt-Konceptsiya “Universal'niy Transportniy Perekhod Cherez Kerchenskiy Proliv" [Project and Concept "Universal Transport Crossing through the Kerch Strait”]. Available at: http://kerch-most.ru/pdf/orig-booklet_3docx.pdf [Accessed 15 August 2017] (in Russian).

4. Kerchenskiy Most: Mifi i Real'nost [Kerch Bridge: Myths and Realities]. [online] Available at: http://history-paradox.ru/kerch-most.php [Accessed 15 August 2017].

5. Nikonov, A.A., 1995. Manifestations of Young Tectonic Activity in the Southern Azov and Kerch Fault Zones (Crimea)]. Geotectonics, 28(5), pp. 380-390. 
6. Pustovitenko, B.G. and Kul'chitskiy, V.E., 1991. Seismichnost' Chernomorskoy Vpadini [The Black Sea Trough Seismisity]. The Journal of Geophysics, 13(1), pp. 14-19 (in Russian).

7. Solov'eva, O.N. and Kuzin, I.P., 2005. Seismicity and Tsunamis in the Northeastern Part of the Black Sea. Oceanology, 45(6), pp.781-794.

8. Ulomov, V.I. and Bogdanov, M.I., 2013. Noviy Komplekt Kart Obshchego Seysmicheskogo Rayonirivaniya Territorii Rossiyskoy Federatsii (OSR-2012) [A New Set of the Seismic Zoning Maps of the Russian Federation (GSZ-2012)]. Inzhenernye izyskaniya, [e-journal] (8), pp. 30-39 (in Russian).

9. Nikonov, A.A., 1997. Tsunami Occurrence on the Coasts of the Black Sea and the Sea of Azov. Izvestiya. Physics of the Solid Earth, [e-journal] 33(1), pp. 77-87.

10. Dotsenko, S.F. and Ingerov, A.V., 2011. Numerical Analysis of the Propagation and Amplification of Tsunami Waves of Seismic Generation in the Sea of Azov]. Physical Oceanography, [e-journal] 21(5), pp. 295-304. doi:10.1007/s11110-012-9123-0

11. Papadopoulos, G.A., Diakogianni, G., Fokaefs, A. and Ranguelov, B., 2011. Tsunami Hazard in the Black Sea and the Azov Sea: A New Tsunami Catalogue. Nat. Hazards Earth Syst. Sci., [e-journal] 11(3), pp. 945-963. doi:10.5194/nhess-11-945-2011

12. Partheniu, R., Diaconescu, M., Ioane, D. and Marmureanu, A., 2015. Tsunami Modeling Scenarios for Some of the Seismic Sources in the Black Sea Area, Using Tsunami Analysis Tool Software. Extended abstract presented at the 8th Congress of the Balkan Geophysical Society, 5-8 October 2015, Chania, Crete. doi:10.3997/2214-4609.201414139

13. Oaie, G., Seghedi, A. and Rădulescu, V., 2016. Natural Marine Hazards in the Black Sea and the System of their Monitoring and Real-Time Warning. Geo-Eco-Marina, 22(2016), pp. 528. http://doi.org/10.5281/zenodo.889593

14. Shnyukov, E.F., Mitin, L.I. and Tsemko, V.P., 1994. Katastrofy $v$ Chyornom more [Catastrophes in the Black Sea]. Kiev: Manuskript, 296 p. (in Russian).

15. Grigorash, Z.K., 1972. Obzor Udalyonnykh Mareogramm Nekotorykh Tsunsami v Chyornom More [The Review of Some Distant Tsunami Mariograms in the Black Sea]. In: SakhKNII, 1972. Trudy SakhKNII [Transactions of Sakhalin Complex Scientific-Research Institute]. Yuzhno-Sakhalinsk: SakhKNII. Iss. 29, pp. 271-278 (in Russian).

16. Dotsenko, S.F., 1998. Tsunami Hazard Assessment for the Black Sea. Moscow University Physics Bulletin, 53(4) pp. 17-22.

17. Dotsenko, S.F., 2005. Evaluation of the Parameters of Tsunami Waves along the South Coast of the Crimean Peninsula. Physical Oceanography, [e-journal] 15(3), pp. 133-141. https://doi.org/10.1007/s11110-005-0036-z

18. Wells, D.L. and Coppersmith, K.J., 1994. New Empirical Relationships among Magnitude, Rupture Length, Rupture Width, Rupture Area, and Surface Displacement. Bull. Seism. Soc. Am., 84(4), pp. 974-1002. Available at: https://www.researchgate.net/publication/215755871_New_Empirical_Relationships_among_ Magnitude_Rupture_Length_Rupture_Width_Rupture_Area_and_Surface_Displacement [Accessed 17 August 2017].

19. Sielecki, A. and Wurtele, M.G., 1970. The Numerical Integration of the Nonlinear ShallowWater Equations with Sloping Boundaries. J. Comput. Phys., 6(2), pp. 219-236. doi:10.1016/0021-9991(70)90022-7

20. Vol'tsinger, N.E., Klevanny, K.A. and Pelinovsky, E.N., 1989. Dlinnovolnovaya Dynamika Pribrezhnoy Zony [Long-Wave Dynamics of the Coastal Zone]. Leningrad: Gidrometeoizdat, 272 p. (in Russian).

21. Mazova, R.Kh., Kiselman, B.A. and Kolchina E.A., 2014. Numerical Simulation of Tsunami Wave Height Distribution for Turkish Black Sea Coast in Nonlinear Dynamic Keyboard Model of Underwater Seismic Source. J. Comput. Applied Mathem., [e-journal] 259(B), pp. 887-896. doi:10.1016/j.cam.2013.08.034

22. Lobkovsky, L.I., Mazova, R.K. and Kolchina, E.A., 2014. Estimation of Maximum Heights of Tsunami Waves for the Sochi Coast from Strong Submarine Earthquakes. Doklady Earth Sciences, [e-journal] 456(2), pp. 749-754. https://doi.org/10.1134/S1028334X14060269 


\section{About the authors:}

Leopold I. Lobkovsky - Deputy Director, Shirshov Institute of Oceanology, Russian Academy of Sciences (36, Nakhimovsky Avenue, Moscow, Russian Federation, 117997), Head of the Laboratory of Seismology and Geodynamics, Corresponding Member of RAS, Dr.Sci. (Phys. and Math.), Professor, ResearcherID:A-6846-2016, llobkovsky@ocean.ru

Raisa Kh. Mazova - Professor of the Applied Mathematics Department, Institute of Radioelectronics and Information Technologies (IRIT), Nizhny Novgorod State Technical University n.a. R.E. Alekseev (NNSTU) (24, Minin St., Nizhny Novgorod, 603950, Russian Federation), Dr.Sci. (Phys. and Math.), Professor, Scopus Author ID: 6506297372, raissamazova@yandex.ru

Elena A. Baranova - Master of the Applied Mathematics Department, Institute of Radioelectronics and Information Technologies (IRIT), Nizhny Novgorod State Technical University n.a. R.E. Alekseev (NNSTU) (24, Minin St., Nizhny Novgorod, 603950, Russian Federation), elenabaranova5995@gmail.com

Artyom M. Tugaryov - Master of the Applied Mathematics Department, Institute of Radioelectronics and Information Technologies (IRIT), Nizhny Novgorod State Technical University n. a. R. E. Alekseev (NNSTU) (24, Minin St., Nizhny Novgorod, 603950, Russian Federation), artyom.tugaryov@gmail.com

\section{Contribution of the co-authors:}

Leopold I. Lobkovsky - general statement of the problem

Raisa Kh. Mazova - scientific supervision of the process of the problem implementation

Elena A. Baranova - numerical modeling of tsunami waves generation and propagation

Artyom M. Tugaryov - spectral analysis of the obtained wave characteristics

All the authors have read and approved the final manuscript.

The authors declare that they have no conflict of interest. 